\section{PERAN DIPLOMASI INDONESIA DALAM PENYELESAIAN SENGKETA DI KAWASAN LAUT CHINA SELATAN PASCA PUTUSAN PERMANENT COURT OF ARBITRATION, $2016^{1}$ Oleh: Steve Michael Massie²}

\begin{abstract}
ABSTRAK
Tujuan dilakukannya penelitian ini yaitu untuk mengetahui bagaimana pengaturan kawasan Laut Teritorial, ZEE dan landas kontinen ditinjau dari Hukum Laut Internasional dan bagaimana peran Diplomasi Indonesia Pasca Putusan PCA dalam Sengketa Kawasan Laut Cina Selatan antara Tiongkok dan Filipina di mana dengan metode penelitian hukum normatif disimpulkan: 1. Konvensi Hukum Laut Internasional UNCLOS 1982, Bab II tentang Laut Teritorial dan Zona Tambahan memuat beberapa ketentuan tentang cara-cara penarikan garis pangkal oleh negara pantai. Pasal 3 menentukan hak negara pantai menetapkan lebar laut teritorial sampai suatu batas yang tidak melebihi 12 mil laut, diukur dari garis pangkal yang ditentukan sesuai dengan Konvensi ini. Demikian dengan cara penarikan garis pangkal pada ZEE dan Landas kontinen selebar 200 mil menurut Pasal 57. Sebaliknya pengaturan hukum disertai ekspansi sepihak oleh Tiongkok terkait dengan cara penarikan garis pangkal laut teritorial metode nine dash line yang dibentangkan hingga ke kawasan ZEE dan Landas Kontinen sekitar LCS karena alasan sejarah, tidak dikenal dan bertentangan dengan Konvensi Hukum Laut Internasional UNCLOS 1982. Tindakan Tiongkok merugikan negara-negara kepulauan yang berada di sekitar LCS, termasuk Indonesia khususnya kawasan wilayah pulau Natuna yang terdampak dari konflik kawasan LCS. 2. Peran diplomasi Indonesia Pasca Putusan PCA dalam Sengketa Kawasan Laut Cina Selatan antara Tiongkok dan Filipina dilakukan berdasarkan Pembukaan Undang-Undang Dasar (UUD) 1945, Alinea Pertama dan Keempat serta Pasal 11, Pasal 13 UUD 1945, serta UU No.24 Tahun 2000 Tentang Perjanjian Internasional UU No.37 Tahun 1999 Tentang Hubungan Luar Negeri. Dilain pihak, peran diplomasi perbatasan atau
\end{abstract}

\footnotetext{
1 Artikel Skripsi. Dosen Pembimbing: Dr. Flora Pricilla Kalalo, SH, MH; Dr. Cornelis Dj. Massie, SH, MH

2 Mahasiswa pada Fakultas Hukum Unsrat, NIM. 16071101229
}

border diplomacy harus dilakukan oleh Indonesia sebagai penguatan khususnya terhadap eksistensi perairan disekitar perairan kepulauan Natuna. Diplomasi perbatasan berupa negosiasi atau perundingan dengan strategi yang tepat, strategi tersebut adalah dengan lebih memfokuskan usaha penguatan ke dalam dengan membangun secara nyata daerah perbatasan sehingga penguasaan secara efektif atau effective occupation terjadi di daerah perbatasan.

Kata kunci: kawasan laut; kawasan lautg china selaran;

\section{PENDAHULUAN}

\section{A. Latar Belakang Masalah}

Kawasan Laut China Selatan (LCS) saat ini menjadi pusat perhatian masyarakat internasional sehubungan dengan Putusan Permanent Court of Arbitration (PCA) pada tanggal 12 Juli 2016 yang menyatakan bahwa klaim Tiongkok (China) atas kawasan perairan LCS yang berdasarkan hak sejarah (historic rights) dengan menggunakan sembilan titik imajiner (Nine dash line) atau sembilan garis putus yang dibentangkan yang ditentukan sendiri oleh Tiongkok, tidak memiliki dasar hukum. Diketahui prinsip nine dash line tidak dikenal dalam ketentuan hukum laut internasional United Nations Convention on the Law of the Sea (UNCLOS) 1982. Tiongkok, akhirnya menolak dan tidak mematuhi putusan PCA tersebut dan tetap menguasai kawasan LCS. $^{3}$

Indonesia sebagai negara kepulauan, meskipun tidak secara langsung terkait dengan klaim Tiongkok di atas, namun Indonesia memiliki kepentingan di kawasan LCS karena salah satu kawasan wilayah perairan dan pulau terluar Indonesia termasuk ZEE pulau Natuna merupakan bagian tak terpisahkan dengan

\footnotetext{
3 Muhammad Rafi Darajati, Huala Adolf, Idris, Putusan Sengketa Laut China Selatan serta Implikasi Hukumnya Terhadap Negara Disekitar Kawasan Tersebut, Jurnal Hukum \& Pembangunan 48 No. 1 (2018): 22-43, ISSN: 0125-9687 (Cetak), E-ISSN: 2503-1465 (Online). Istilah Tiongkok berdasarkan pada Keputusan Presiden Nomor 12 Tahun 2014 tentang Pencabutan Surat Edaran Presidium Kabinet Ampera Nomor SE-06/PRES.KAB/6/1967. Sedangkan penyebutan terhadap istilah Laut China Selatan tidak diubah menjadi Laut Tiongkok Selatan karena Keputusan Presiden tersebut hanya menetapkan pengubahan terhadap istilah orang dan atau komunitas, dan penyebutan negara.
} 
kedaulatan wilayah negara. Pulau Natuna Indonesia merupakan wilayah terdampak dari sengketa LCS oleh karena itu diperlukan upaya pencegahan agar tidak terseret jauh pada sengketa kawasan LCS. Upaya pencegahan dapat dilakukan melalui peran diplomasi Indonesia, peran diplomasi juga dibutuhkan dalam rangka penyelesaian sengketa kawasan laut teritorial, ZEE dan Landas Kontinen antara negara-negara di sekitar kawasan wilayah LCS. Diplomasi Indonesia dilaksanakan berdasarkan Pembukaan Undang-Undang Dasar (UUD) 1945, Alinea Pertama dan Keempat serta Pasal 11, Pasal 13 UUD 1945, serta UU No.24 Tahun 2000 Tentang Perjanjian Internasional UU No.37 Tahun 1999 Tentang Hubungan Luar Negeri.

\section{B. Rumusan Masalah}

1. Bagaimana pengaturan kawasan Laut Teritorial, ZEE dan landas kontinen ditinjau dari Hukum Laut Internasional ?

2. Bagaimana peran Diplomasi Indonesia Pasca Putusan PCA dalam Sengketa Kawasan Laut Cina Selatan antara Tiongkok dan Filipina?

\section{Metode Penelitian}

Penelitian ini merupakan bagian dari penelitian hukum yakni dengan cara meneliti bahan pustaka yang dinamakan penelitian hukum kepustakaan.

\section{PEMBAHASAN}

A. Pengaturan Wilayah Laut Teritorial ditinjau dari Hukum Laut Internasional

1. Penarikan garis pangkal laut teritorial metode nine dash line yang diklaim oleh Tiongkok bertentangan dengan konvensi hukum laut Unclos 1982

Penarikan garis pangkal laut metode nine dash line telah dibentangkan dari wilayah laut teritorial negara Tiongkok hingga menyentuh ke wilayah laut teritorial, zona ekonomi eksklusif dan landas kontinen yang diklaim oleh negaranegara di sekitar LCS. Penerapan metode nine dash line oleh pihak Tiongkok diikuti dengan upaya penegakan hukum secara sepihak berlaku di kawasan LCS. Meskipun demikian penerapan metode straight base nine dash line tidak dikenal di dalam doktrin hukum laut maupun pengaturan Konvensi Hukum Laut UNCLOS 1982. Oleh karena itu Putusan PCA menyatakan penggunaan metode nine dash line dari Tiongkok tak dapat diterima karena bertentangan dengan Konvensi Hukum Laut Internasional dan jelas sebagai pelanggaran terhadap hukum internasional.

Metode nine dash line ini bukannya tanpa dasar namun metode yang diklaim tersebut oleh pihak Tiongkok diakui sebagai dasar sejarah (historis). Dasar historis menurut pihak Tiongkok bahwa peta kepulauan Laut Cina Selatan telah diterbitkan di seluruh dinasti Ming dan Qing, termasuk peta navigasi yang disusun pada abad ke-13 oleh Laksamana Cheng Ho. Klaim Tiongkok berdasarkan pada pemahaman bahwa fitur teritorial Laut Cina Selatan merupakan wilayah yang secara historis dimiliki oleh Tiongkok atas yurisdiksi berdaulat yakni "hak milik leluhur" yang diturunkan dari generasi sebelumnya. ${ }^{4}$

Beberapa dasar klaim Tiongkok bahwa: ${ }^{5}$

a. Kegiatan Tiongkok di Laut Cina Selatan telah terjadi lebih dari 2000 tahun yang lalu".

b. Tiongkok menjadi negara pertama yang menemukan, menamai, mengeksplorasi dan mengeksploitasi sumber daya dari pulau-pulau Laut Cina Selatan dan yang pertama untuk terus-menerus menggunakan kekuatan berdaulat atas wilayah itu.

c. Kepemilikan Tiongkok atas pulau-pulau Laut Cina Selatan telah diakui oleh Inggris, Jerman, Perancis, dan atlas daerah Soviet yang diterbitkan pada tahun 1950-1960an.

d. Pemerintah Tiongkok menolak klaim teritorial oleh penuntut Laut Cina Selatan lainnya (terutama Filipina). Klaim teritorial itu seharusnya tidak mencakup fitur laut di dalam area garis putus-putus sampai tahun 1970-an.

e. Dari perspektif Beijing menunjukkan bahwa klaim dari negara-negara lain relatif baru, bermotivasi politik, dan lebih lanjut didorong oleh ekstraksi sumber daya.

\footnotetext{
${ }^{4}$ Institut for Security \& Development Policy, Understanding China's Position on the South China's Disputes, June 2016. http://isdp.eu/publication/understanding-chinas-positionsouth-china-sea-disputes/ diakses pada tanggal 22 November 2019.

5 lbid.
} 
Melalui dasar penggunaan metode garis bentangan nine dash line wilayah laut, maka Tiongkok melakukan penguasaan terhadap beberapa pulau di kawasan LCS, antara lain:

a. Kawasan pulau yang tidak berpenghuni Mischief Reef, yang diklaim oleh Filipina dan Tiongkok.

b. Kawasan bagian timur dari kelompok Pulau Spratly yang diduduki oleh Tiongkok. Pulau Spratly ini diklaim bersama oleh 4 (empat) negara.

c. Pulau Paracel diduduki oleh Tiongkok yang juga di klaim oleh Vietnam.

d. Tiongkok (Taiwan) memaksa menduduki Pulau Pratas Reef.

e. Disamping Tiongkok, Malaysia juga telah mendirikan resort di Swallow Reef.

Perairan LCS yang luasnya kurang lebih 3.500.000 kilometer persegi itu, termasuk pulau-pulau yang berada disekitarnya diklaim kepemilikannya oleh 10 negara yakni Tiongkok, Indonesia, Taiwan, Filipina, Vietnam, Thailand, Brunei, Malaysia, Singapura, Kamboja. Tiongkok sendiri mengklaim perairan LCS atas dasar 9 (Sembilan) garis putus yang dibentangkan di kawasan wilayah LCS yang meliputi Zona Ekonomi Eksklusif (ZEE) dari Brunei, Indonesia, Malaysia, Filipina, Singapura, Taiwan, dan Vietnam.

Vietnam melakukan klaim di sekitar perbatasan wilayah kelautan di sepanjang pesisir Vietnam, dan Kepulauan Paracel.

Taiwan mengklaim beberapa wilayah di kepulauan Spratly dan Gosong Scarborough (yang juga dipersengketakan Filipina dan Tiongkok).

Kepulauan Spratly sendiri dipersengketakan antara Tiongkok dan 5 (lima) negara yakni Taiwan, Vietnam, Filipina, Malaysia dan Brunei Darusalam. Persoalan terjadi di tahun 1996 sewaktu Jepang mendirikan mercusuar di pulau Spratly, tetapi Tiongkok dan Taiwan juga secara bersama menuntut kepemilikan atas pulau tersebut. Demikian juga Filipina dan Malaysia masing-masing menuntut bagian tumpang tindih dari kelompok pulau-pulau Spratly.

Cara penguasaan wilayah laut dengan penarikan garis pangkal laut teritorial metode nine dash line yang diklaim oleh Tiongkok merupakan metode baru sebagai praktik negara dan telah diuji melalui peradilan PCA. Walaupun akhirnya putusan PCA 2016 itu tidak dapat diterima dan ditolak oleh pihak Tiongkok. Padahal PCA merupakan lembaga peradilan yang dibentuk oleh masyarakat internasional, diakui dan berada dalam sistem lex specialis hukum internasional yakni hukum laut internasional UNCLOS 1982. Penolakan atas putusan PCA menjadi tantangan hukum internasional.

\section{Penarikan garis pangkal laut teritorial, ZEE dan landas kontinen menurut konvensi hukum laut Unclos 1982}

Konvensi Hukum Laut (KHL) PBB telah dinyatakan diterima tanggal 30 April 1982 dan ditandatangani pada 10 Desember 1982 di Montego Bay, Jamaica, serta dinyatakan mulai berlaku secara internasional sejak tanggal 16 November 1994. Dengan demikian untuk pertama kali terdapat ketentuan hukum internasional mengenai lebar laut wilayah. Indonesia sendiri meratifikasi $\mathrm{KHL}$ ini dengan Undang-Undang No.17 Tahun 1985 tentang Pengesahan Konvensi Hukum Laut Internasional PBB itu.

Ketentuan ini sangat penting dalam rangka mengurangi salah satu sumber kemungkinan sengketa antara negara-negara dalam hubungannya satu sama lain di bidang hukum laut. Menyangkut penerimaan lebar laut wilayah 12 mil tidak begitu mendapat kesukaran karena sudah merupakan kecenderungan umum semenjak beberapa tahun sebelumnya. ${ }^{6}$

a. Penarikan Garis Pangkal Wilayah Laut Teritorial

Konvensi Hukum Laut Internasional UNCLOS 1982, Bab II tentang Laut Teritorial dan Zona Tambahan memuat beberapa ketentuan tentang cara-cara penarikan garis pangkal oleh negara pantai. Pasal 3 menentukan hak negara pantai menetapkan Lebar laut teritorial: Setiap Negara mempunyai hak untuk menetapkan lebar laut teritorialnya sampai suatu batas yang tidak melebihi 12 mil laut, diukur dari garis pangkal yang ditentukan sesuai dengan Konvensi ini. Pasal 4 menentukan batas terluar laut teritorial,

\footnotetext{
${ }^{6}$ Boer Mauna, Loc.Cit. HIm.371
} 
Batas terluar laut teritorial adalah garis yang jarak setiap titiknya dari titik yang terdekat garis pangkal, sama dengan lebar laut teritorial.

Pasal 5 Konvensi 1982 memuat ketentuan tentang garis pangkal yang normal atau garis pangkal biasa (normal baseline) sebagai berikut:

Kecuali ditentukan lain dalam Konvensi ini, garis pangkal biasa untuk mengukur lebar laut teritorial adalah garis air rendah sepanjang pantai sebagaimana yang ditandai pada peta skala besar yang secara resmi diakui oleh Negara pantai tersebut.

Menurut pasal 5 tersebut, garis pangkal biasa untuk mengukur lebar laut teritorial adalah garis air rendah sepanjang pantai sebagai mana terlihat pada peta skala besar yang diakui resmi oleh negara pantai tersebut. Hal ini adalah cara klasik yang dipergunakan semenjak dulu. Tetapi cara penarikan garis pangkal yang demikian ternyata sukar dalam pelaksanaannya terutama bagi negara-negara yang mempunyai pantai-pantai yang berliku-liku serta yang mempunyai pulau yang banyak di dekat pantai-pantai. Ketentuan ini kemudian ditegaskan olah Pasal 7 ayat 1 Konvensi 1982. Di samping itu penarikan garis lurus ini tidak dapat dilakukan begitu saja, tetapi ada ketentuan-ketentuannya pula. Ketentuan-ketentuan ini diatur oleh ayat-ayat 2, 3, 4, 5 dan $6 .^{7}$

Pasal 7 ayat 1 Konvensi Hukum Laut 1982 tentang penarikan Garis pangkal lurus (straight baselines) menyatakan : Di tempat-tempat dimana garis pantai menjorok jauh ke dalam dan menikung ke dalam atau jika terdapat suatu deretan pulau sepanjang pantai di dekatnya, cara penarikan garis pangkal lurus yang menghubungkan titik-titik yang tepat dapat digunakan dalam menarik garis pangkal dari mana lebar laut teritorial diukur.

Lebih lanjut disebutkan oleh ayat 2 , ayat 3 , ayat 4 , ayat 5 dan ayat 6 , sebagai berikut:
Ayat 2 menyatakan, Dimana karena adanya suatu delta dan kondisi alam lainnya garis pantai sangat tidak tetap, maka titik-titik yang tepat dapat dipilih pada garis air rendah yang paling jauh menjorok ke laut dan sekalipun garis air rendah kemudian mundur, garis-garis pangkal lurus tersebut akan tetap berlaku sampai dirobah oleh Negara pantai sesuai dengan Konvensi ini.

Ayat 3, Penarikan garis pangkal lurus tersebut tidak boleh menyimpang terlalu jauh dari arah umum dari pada pantai dan bagian-bagian laut yang terletak di dalam garis pangkal demikian harus cukup dekat ikatannya dengan daratan untuk dapat tunduk pada rezim perairan pedalaman.

Ayat 4, Garis pangkal lurus tidak boleh ditarik ke dan dari elevasi surut kecuali jika di atasnya didirikan mercu suar atau instalasi serupa yang secara permanen ada di atas permukaan laut atau kecuali dalam hal penarikan garis pangkal lurus ke dan dari elevasi demikian telah memperoleh pengakuan umum internasional.

Ayat 5, Dalam hal cara penarikan garis pangkal lurus dapat diterapkan berdasarkan ayat 1, maka di dalam menetapkan garis pangkal tertentu, dapat ikut diperhitungkan kepentingan ekonomi yang khusus bagi daerah yang bersangkutan, yang kenyataan dan pentingnya secara jelas dibuktikan oleh praktek yang telah berlangsung lama.

Ayat 6, Sistem penarikan garis pangkal lurus tidak boleh diterapkan oleh suatu Negara dengan cara yang demikian rupa sehingga memotong laut teritorial Negara lain dari laut lepas atau zona ekonomi eksklusif.

Pengaturan konvensi hukum laut tersebut di atas menegaskan bahwa penarikan garis pangkal lurus tersebut tidak boleh menyimpang terlalu jauh dari arah umum pantai dan bagian-bagian laut yang terletak di dalam garis pangkal itu harus cukup dekat dengan ikatannya dengan daratan untuk dapat tunduk pada rezim perairan pedalaman. Garis pangkal lurus tidak boleh ditarik ke dan

7lbid. HIm.371 
dari elevasi surut, kecuali jika diatasnya didirikan mercusuar atau instalasi serupa yang secara permanen ada di atas permukaan laut atau kecuali dalam hal penarikan garis pangkal lurus ke dan dari elevasi demikian telah memperoleh pengakuan umum internasional. Sistem penarikan garis pangkal lurus tidak boleh diterapkan oleh suatu negara dengan cara yang demikian rupa sehingga memotong laut teritorial negara lain dari laut lepas atau zona ekonomi eksklusif. Cara penarikan garis lurus ini didasarkan atas keputusan Mahkamah Internasional 28 Desember 1951 dalam sengketa Anglo Norwegian Fisheries Case. Sengketanya ialah Inggris menolak dan tidak mentaati penetapan batas perikanan eksklusif yang ditetapkan oleh Norwegia dalam Firman Raja (Royal Decrees) 1935. Gugatan Inggris bukanlah lebar laut wilayah baru 4 mil tetapi cara penarikan garis pangkal lurus yang menghubungkan titik-titik terluar pada pantai Norwegia dan melalui pulau-pulau di muka pantai (skjaergaard). Penarikan garis pangkal yang demikian menyebabkan banyaknya bagian-bagian laut yang sebelumnya merupakan laut lepas menjadi laut wilayah atau perairan pedalaman sehingga kapal-kapal ikan Inggris yang biasanya menangkap ikan di tempattempat tersebut tidak boleh lagi datang kesana. Dalam keputusannya, Mahkamah membenarkan cara penarikan garis pangkal yang demikian. Walaupun menurut Pasal 59 Statuta Mahkamah, keputusan itu hanya mengikat pihakpihak yang bersengketa, namun selanjutnya cara penarikan garis pangkal lurus tersebut diakui sebagai suatu ketentuan umum yang selanjutnya dikukuhkan oleh Konvensi Jenewa 1958 tentang Laut Wilayah.

Menyangkut status hukum dari laut yang terletak di sisi dalam sebagai akibat dari penarikan garis pangkal lurus. Persoalan ini telah di tegaskan oleh Konvensi Hukum Laut 1982 Pasal 8 ayat 1 tentang Perairan pedalaman (internal waters) yang menyebutkan:
Kecuali sebagaimana diatur dalam bab IV, perairan pada sisi darat garis pangkal laut teritorial merupakan bagian perairan pedalaman Negara tersebut.

Selanjutnya Pasal 8 ayat 2 menentukan, Dalam hal penetapan garis pangkal lurus sesuai dengan cara yang ditetapkan dalam pasal 7 berakibat tertutupnya sebagai perairan pedalaman daerahdaerah yang sebelumnya tidak dianggap demikian, maka di dalam perairan demikian akan berlaku suatu hak lintas damai sebagaimana ditentukan dalam Konvensi ini.

Ketentuan ini merupakan suatu hal yang baru pula dalam hukum laut dengan adanya laut pedalaman yang mempunyai hak lintas damai seperti di laut wilayah.

Cara-cara penetapan garis pangkal oleh negara pantai diatur berdasarkan Pasal 14 Konvensi yang menegaskan, Negara pantai dapat menetapkan garis pangkal secara bergantian dengan menggunakan cara penarikan manapun yang diatur dalam pasal-pasal di atas untuk menyesuaikan dengan keadaan yang berlainan.

Penetapan garis batas laut teritorial antara negara-negara yang pantainya berhadapan atau berdampingan diatur menurut Pasal 15 yang menyatakan, Dalam hal pantai dua Negara yang letaknya berhadapan atau berdampingan satu sama lain, tidak satupun di antaranya berhak, kecuali ada persetujuan yang sebaliknya antara mereka, untuk menetapkan batas laut teritorialnya melebihi garis tengah yang titiktitiknya sama jaraknya dari titik-titik terdekat pada garis-garis pangkal dari mana lebar laut teritorial masing-masing Negara diukur. Tetapi ketentuan di atas tidak berlaku, apabila terdapat alasan hak historis atau keadaan khusus lain yang menyebabkan perlunya menetapkan batas laut teritorial antara kedua Negara menurut suatu cara yang berlainan dengan ketentuan di atas.

Menyangkut Garis pangkal untuk mengukur lebar laut teritorial harus dicantumkan dalam Peta dan daftar koordinat geografis dari negara pantai, 
sebagaimana ditentukan oleh Pasal 16 Konvensi Hukum Laut UNCLOS 1982, sebagai berikut:

1) Garis pangkal untuk mengukur lebar laut teritorial sebagaimana ditetapkan sesuai dengan pasal 7, 9 dan 10, atau garis batas yang diakibatkan oleh ketentuan-ketentuan itu dan garis batas yang ditarik sesuai dengan pasal 12 dan 15, harus dicantumkan dalam peta dengan skala atau skala-skala yang memadai untuk penetapan garis posisinya. Sebagai gantinya dapat diberikan suatu daftar titik-titik koordinat geografis, yang menjelaskan datum geodetik.

2) Negara pantai harus memberikan pengumuman sebagaimana mestinya mengenai peta atau daftar koordinat geografis tersebut dan mendepositkan satu copy/turunan setiap peta atau daftar tersebut kepada Sekretaris Jenderal Perserikatan Bangsa-Bangsa.

b. Penarikan Garis Pangkal Lebar Zona Ekonomi Eksklusif

Sebagaimana cara penarikan garis pangkal pada laut teritorial dari mana lebar laut teritorial 12 mil diukur, maka cara penarikan garis pangkal yang berbeda pada penetapan garis pangkal di ZEE dan landas kontinen yakni dengan jarak lebar laut 200 mil.

Pasal 57 menyebutkan, Lebar zona ekonomi eksklusif tidak boleh melebihi 200 mil laut dari garis pangkal darimana lebar laut teritorial diukur.

Rezim hukum yang berlaku pada ZEE yakni rezim hukum khusus zona ekonomi eksklusif berdasarkan Pasal 55 yang menyatakan: Zona ekonomi eksklusif adalah suatu daerah di luar dan berdampingan dengan laut teritorial, yang tunduk pada rejim hukum khusus yang ditetapkan dalam Bab ini berdasarkan mana hak-hak dan yurisdiksi Negara pantai dan hak-hak serta kebebasan-kebebasan Negara lain, diatur oleh ketentuan-ketentuan yang relevan Konvensi ini.

Menurut Pasal 56, Hak-hak, yurisdiksi dan kewajiban Negara pantai dalam ZEE,
Dalam zona ekonomi eksklusif, negara pantai mempunyai :

1) Hak-hak berdaulat untuk keperluan eksplorasi dan eksploitasi, konservasi dan pengelolaan sumber kekayaan alam, baik hayati maupun non-hayati, dari perairan di atas dasar laut dan dari dasar laut dan tanah di bawahnya dan berkenaan dengan kegiatan lain untuk keperluan eksplorasi dan eksploitasi ekonomi zona tersebut, seperti produksi energi dari air, arus dan angin;

2) Yurisdiksi sebagaimana ditentukan dalam ketentuan yang relevan Konvensi ini berkenaan dengan :

a) pembuatan dan pemakaian pulau buatan, instalasi dan bangunan;

b) riset ilmiah kelautan;

c) perlindungan dan pelestarian lingkungan laut;

3) Hak dan kewajiban lain sebagaimana ditentukan dalam Konvensi ini.

4) Di dalam melaksanakan hak-hak dan memenuhi kewajibannya berdasarkan Konvensi ini dalam zona ekonomi eksklusif, Negara Pantai harus memperhatikan sebagaimana mestinya hak-hak dan kewajiban Negara lain dan harus bertindak dengan suatu cara sesuai dengan ketentuan Konvensi ini.

5) Hak-hak yang tercantum dalam pasal ini berkenaan dengan dasar laut dan tanah di bawahnya harus dilaksanakan sesuai dengan Bab VI.

Dasar untuk penyelesaian sengketa mengenai pemberian hak-hak dan yurisdiksi di zona ekonomi eksklusif diatur berdasarkan Pasal 59 yang menyatakan :

Dalam hal dimana Konvensi ini tidak memberikan hak-hak atau yurisdiksi kepada Negara pantai atau kepada Negara lain di zona ekonomi eksklusif, dan timbul sengketa antara kepentinganan-kepentingan Negara pantai dan Negara lain atau Negaranegara lain manapun, maka sengketa itu harus diselesaikan berdasarkan keadilan dan dengan pertimbangan segala keadaan yang relevan, dengan 
memperhatikan masing-masing keutamaan kepentingan yang terlibat bagi para pihak maupun bagi masyarakat internasional secara keseluruhan.

c. Penarikan Garis Pangkal Lebar Landas Kontinen

Batasan landas kontinen diatur menurut Pasal 76 yang menyatakan,

1) Landas kontinen suatu Negara pantai meliputi dasar laut dan tanah di bawahnya dari daerah di bawah permukaan laut yang terletak di luar laut teritorialnya sepanjang kelanjutan alamiah wilayah daratannya hingga pinggiran luar tepi kontinen, atau hingga suatu jarak 200 mil laut dari garis pangkal darimana lebar laut teritorial diukur, dalam hal pinggiran luar tepi kontinen tidak mencapai jarak tersebut.

2) Landas kontinen suatu negara pantai tidak boleh melebihi batas-batas sebagaimana ditentukan dalam ayat 4 hingga 6.

3) Tepian kontinen meliputi kelanjutan bagian daratan negara pantai yang berada dibawah permukaan air, dan terdiri dari dasar laut dan tanah dibawahnya dari dataran kontinen, lereng (slope) dan tanjakan (rise). Tepian kontinen ini tidak mencakup dasar samudera dalam dengan buktibukti samudera atau tanah di bawahnya.

4) a) Untuk maksud konvensi ini, Negara pantai akan menetapkan pinggiran luar tepian kontinen dalam hal tepian kontinen tersebut lebih lebar dari 200 mil laut dari garis pangkal dan mana lebar laut teritorial diukur, atau dengan :

(1) suatu garis yang ditarik sesuai dengan ayat 7 dengan menunjuk pada titik tetap terluar dimana ketebalan batu endapan adalah paling sedikit $1 \%$ dari jarak terdekat antara titik tersebut dan kaki lereng kontinen; atau

(2) suatu garis yang ditarik sesuai dengan menunjuk pada titiktitik tetap yang tereltak tidak lebih dari 60 mil kaut dari kaki lereng kontinen.

b) Dalam hal tidak terdapatnya bukti yang bertentangan, kaki lereng kontinen harus ditetapkan sebagai titik perubahan maksimum dalam tanjakan pada kakinya.

5) Titik-titik tetap yang merupakan garis batas luar landas kontinen pada dasar laut, yang ditarik sesuai dengan ayat 4 (a)(i) dan (ii), atau tidak akan boleh melebihi 350 mil laut dari garis pangkal dari mana laut teritorial diukur atau tidak boleh melebihi 100 mil laut dari garis batas kedalaman (isobath) 2.500 meter, yaitu suatu garis yang menghubungkan kedalaman 2.500 meter.

6) Walaupun ada ketentuan ayat 5, pada bukti-bukti dasar laut, batas luar landas kontinen tidak boleh melebihi 350 mil laut dari garis pangkal dari mana laut teritorial diukur. Ayat ini tidak berlaku bagi elevasi dasar laut yang merupakan bagian-bagian alamiah tepian kontinen, seperti pelataran (pateau), tanjakan (rise), puncak (caps), ketinggian yang datar (banks) dan puncak gunung yang bulat (spurs) nya.

7) Negara pantai harus menetapkan batas terluar landas kontinennya di mana landas kontinen itu melebihi 200 mil laut dari garis pangkal dari mana laut teritorial diukur dengan cara menarik garis-garis lurus yang tidak melebihi 60 mil laut panjangnya, dengan menghubungkan titik-titik tetap, yang ditetapkan dengan koordinat-koordinat lintang dan bujur.

8) Keterangan mengenai batas-batas landas kontinen di luar 200 mil laut dari garis pangkal dari mana laut teritorial diukur harus disampaikan oleh Negara pantai kepada Komisi Batas-batas Landas Kontinen (Commision on the Limits of the Continental Shelf) yang didirikan berdasarkan Lampiran II atas dasar perwakilan geografis yang adil. Komisi ini harus membuat rekomendasi kepada Negara pantai mengenai masalah yang bertalian dengan penetapan batas luar landas kontinen 
mereka. Batas-batas landas kontinen yang ditetapkan oleh suatu Negara pantai berdasarkan rekomendasirekomendasi ini adalah tuntas dan mengikat.

9) Negara pantai harus mendepositkan pada Sekretaris Jenderal Perserikatan Bangsa-Bangsa peta-peta dan keterangan yang relevan termasuk data geodesi, yang secara permanen menggambarkan batas luar landas kontinennya Sekretaris Jenderal harus mengumumkan peta-peta dan keterangan tersebut sebagaimana mestinya.

10) Ketentuan pasal ini tidak boleh mengurangi arti masalah penetapan batas landas kontinen antara Negaranegara yang berhadapan atau berdampingan.

Menyangkut penetapan garis batas landas kontinen antara negara yang pantainya berhadapan atau berdampingan, maka Pasal 83 menegaskan bahwa:

1) Penetapan garis batas landas kontinen antara Negara yang pantainya berhadapan atau berdampingan harus dilakukan dengan persetujuan atas dasar hukum internasional, sebagaimana tercantum dalam Pasal 38 Statuta Mahkamah Internasional untuk mencapai suatu penyelesaian yang adil.

2) Apabila tidak dapat dicapai persetujuan dalam jangka waktu yang pantas, Negara yang bersangkutan harus menggunakan prosedur yang ditentukan dalam Bagian XV.

3) Sambil menunggu persetujuan sebagaimana ditentukan dalam ayat 1 , Negara-negara yang bersangkutan, dengan semangat saling pengertian dan kerjasama, harus membuat segala usaha untuk mengadakan pengaturan sementara yang bersifat praktis dan, selama masa peralihan ini, tidak membahayakan atau mengganggu pencapaian persetujuan yang tuntas. Pengaturan demikian tidak boleh merugikan penetapan garis batas yang tuntas.

4) Dalam hal ada suatu persetujuan yang berlaku antara Negara-negara yang bersangkutan, masalah yang bertalian dengan penetapan garis batas landas kontinen harus ditetapkan sesuai dengan ketentuan persetujuan itu.

\section{B. Peran Diplomasi Indonesia Pasca Putusan PCA dalam Sengketa Kawasan Laut Cina Selatan antara Tiongkok dan Filipina}

Klaim berbagai negara yang berbatasan dengan LCS yang dilancarkan telah memunculkan kekhawatiran negara pengklaim dan non pengklaim di sekitarnya serta negara luar kawasan atas masa depan kontrol, stabilitas, dan keamanan wilayah perairan di sana. Kekuatiran yang meningkat kemudian telah memicu eskalasi ketegangan akibat muncul kegiatan-kegiatan militer dan saling unjuk kekuatan angkatan bersenjata serta upaya provokasi di daerah LCS. Selanjutnya diperlihatkan pula perilaku agresif dan beberapa upaya provokasi yang dilakukan angkatan laut Tiongkok di wilayah LCS terhadap angkatan laut dan nelayan asal Filipina dan Vietnam, atau sebaliknya. Aksi saling cegah dan usir dari kawasan perairan yang dipersengketakan itu terus meningkat dan cenderung mengarah pada terciptanya konflik berskala rendah. Konflik bersenjata terbuka secara luas dengan intensitas tinggi tetap saja terbuka jika resolusi konflik permanen gagal ditemukan mengingat besarnya dan banyaknya kepentingan baik dari negara yang mengklaim, negara non pengklaim, serta negara luar kawasan. ${ }^{8}$

Salah satu negara yang gencar melakukan protes terhadap klaim Tiongkok atas hampir seluruh wilayah Laut Tiongkok Selatan adalah Filipina. Pada bulan Januari 2013, Filipina membawa sengketa LCS ke Permanet Court of Arbitration (PCA). Pada tanggal 12 Juli 2016, PCA, mengeluarkan putusan atas gugatan Filipina melawan Tiongkok mengenai masalah LCS, sesuai permohonan Filipina, putusan PCA menafsirkan mengklarifikasi persoalan yang selama ini dianggap rancu dalam pusaran konflik LCS bahwa:9 "The Tribunal concludes

\footnotetext{
8 Muhammad Rafi Darajati, Huala Adolf, Idris, Putusan Sengketa Laut China Selatan serta Implikasi Hukumnya Terhadap Negara Disekitar Kawasan Tersebut, Jurnal Hukum \& Pembangunan 48 No. 1 (2018): 22-43, ISSN: 0125-9687 (Cetak), E-ISSN: 2503-1465 (Online). 9 Ibid
} 
that, as between the Philippines and China, China's claims to historic rights, or other sovereign rights or jurisdiction, with respect to the maritime areas of the South China Sea encompassed by the relevant part of the 'ninedash line' are contrary to the Convention and without lawful effect to the extent that they exceed the geographic and substantive limits of China's maritime entitlements under the Convention. The Tribunal concludes that the Convention superseded any historic rights or other sovereign rights or jurisdiction in excess of the limits imposed therein". Pada intinya PCA mengklarifikasi klaim Tiongkok mengenai historic rights sehubungan dengan wilayah maritim di LCS yang diklaim dengan menggunakan nine-dash line merupakan hal yang bertentangan dengan Konvensi Hukum Laut 1982. Akan tetapi pihak Tiongkok mengatakan bahwa mereka tidak menerima dan tidak akan mengakui putusan dari PCA tersebut. Pihak Kementerian Luar Negeri Tiongkok mengatakan bahwa putusan itu tak memiliki kekuatan yang mengikat sehingga Tiongkok tidak akan menerima atau mengakui putusan tersebut. ${ }^{8}$ Adapun pernyataan yang dikeluarkan oleh Tiongkok terkait putusan PCA tersebut adalah: ${ }^{10}$ "The ruling is null and void with no binding force. It will in no way affect China's territorial sovereignty and maritime rights and interests in the South China Sea. We oppose and refuse to accept any proposal or action based on the ruling. China will continue to safeguard territorial sovereignty and maritime rights and interests, maintain peace and stability in the South China Sea, and endeavor to peacefully resolve relevant disputes in the South China Sea with parties directly concerned through negotiation and consultation on the basis of respecting historical facts and in accordance with international law".

Walaupun telah terdapat putusan hukum yang mengatakan bahwa nine-dash line tidak dibenarkan berdasarkan hukum laut internasional, akan tetapi keengganan Tiongkok untuk mematuhi putusan tersebut juga harus menjadi kewaspadaan. Keengganan Tiongkok untuk mematuhi putusan dari PCA dan tetap melakukan agresivitas di kawasan LCS dapat

\footnotetext{
$10 \mathrm{lbid}$
}

memperparah hubungan dengan negaranegara sekitar kawasan LCS.

Peran diplomasi Indonesia terhadap penyelesaian sengketa kawasan LCS dinilai sangat penting sejalan dengan Pembukaan Undang-Undang Dasar (UUD) 1945, Alinea Pertama dan Keempat serta Pasal 11, Pasal 13 UUD 1945, serta UU No.24 Tahun 2000 Tentang Perjanjian Internasional UU No.37 Tahun 1999 Tentang Hubungan Luar Negeri. Dilain pihak, peran diplomasi perbatasan atau border diplomacy harus dilakukan oleh Indonesia sebagai penguatan khususnya terhadap eksistensi perairan disekitar perairan kepulauan Natuna. Diplomasi perbatasan berupa negosiasi atau perundingan dengan strategi yang tepat, strategi tersebut adalah dengan lebih memfokuskan usaha penguatan ke dalam dengan membangun secara nyata daerah perbatasan sehingga penguasaan secara efektif atau effective occupation terjadi di daerah perbatasan. ${ }^{11}$

Penguatan kedalam dengan melakukan pembangunan harus diikuti dengan upaya penegakan hukum atau law enforcement. Undang-Undang No 17 tahun 1985 diyakini mengandung prinsip-prinsip kepastian hukum, kemanfaatan, dan keadilan. Jika penarikan garis pangkal lurus kepulauan yang menghubungkan titik-titik terluar pulau-pulau dan karang kering keluar kepulauan di Indonesia mengacu pada pasal 47 UNCLOS 1982 tersebut, maka secara yuridis jumlah keseluruhan pulau di Indonesia menjadi 17.508 pulau, termasuk pulau Natuna dan sekitarnya. ${ }^{12}$ Diplomasi perbatasan juga sebagai implementasi kedaulatan negara yang diwujudkan melalui gagasan nasional poros maritim dunia yang merupakan faktor geostrategi Indonesia.

Permanent Court of Arbitration (PCA) atau Mahkamah Arbitrase Permanen merupakan salah satu lembaga peradilan dalam sistem Hukum Laut Internasional pilihan para pihak bersengketa yang diatur di dalam Pasal 287 Ayat (1) UNCLOS 1982 yang menyatakan:

Pada waktu menandatangani, meratifikasi atau aksesi pada Konvensi ini atau pada setiap waktu setelah itu, suatu Negara bebas untuk memilih, dengan membuat pernyataan tertulis, satu atau lebih dari cara-cara berikut untuk

\footnotetext{
${ }^{11}$ Cornelis Djelfie Massie, Loc.Cit. HIm 63

12Ibid. hIm 64
} 
menyelesaikan sengketa perihal interprestasi atau penerapan Konvensi ini :

1. Mahkamah Internasional Hukum Laut yang dibentuk sesuai denngan Lampiran $\mathrm{VI}$;

2. Mahkamah Internasional;

3. Suatu mahkamah arbitrasi khusus yang dibentuk sesuai dengan Lampiran VIII;

4. Suatu mahkamah arbitrasi khusus yang dibentuk sesuai dengan Lampiran VIII untuk satu jenis sengketa atau lebih yang tertera didalamnya.

\section{PENUTUP}

\section{A. Kesimpulan}

1. Konvensi Hukum Laut Internasional UNCLOS 1982, Bab II tentang Laut Teritorial dan Zona Tambahan memuat beberapa ketentuan tentang cara-cara penarikan garis pangkal oleh negara pantai. Pasal 3 menentukan hak negara pantai menetapkan lebar laut teritorial sampai suatu batas yang tidak melebihi 12 mil laut, diukur dari garis pangkal yang ditentukan sesuai dengan Konvensi ini. Demikian dengan cara penarikan garis pangkal pada ZEE dan Landas kontinen selebar 200 mil menurut Pasal 57. Sebaliknya pengaturan hukum disertai ekspansi sepihak oleh Tiongkok terkait dengan cara penarikan garis pangkal laut teritorial metode nine dash line yang dibentangkan hingga ke kawasan ZEE dan Landas Kontinen sekitar LCS karena alasan sejarah, tidak dikenal dan bertentangan dengan Konvensi Hukum Laut Internasional UNCLOS 1982. Tindakan Tiongkok merugikan negara-negara kepulauan yang berada di sekitar LCS, termasuk Indonesia khususnya kawasan wilayah pulau Natuna yang terdampak dari konflik kawasan LCS.

2. Peran diplomasi Indonesia Pasca Putusan PCA dalam Sengketa Kawasan Laut Cina Selatan antara Tiongkok dan Filipina dilakukan berdasarkan Pembukaan UndangUndang Dasar (UUD) 1945, Alinea Pertama dan Keempat serta Pasal 11, Pasal 13 UUD 1945, serta UU No.24 Tahun 2000 Tentang Perjanjian Internasional UU No.37 Tahun 1999 Tentang Hubungan Luar Negeri. Dilain pihak, peran diplomasi perbatasan atau border diplomacy harus dilakukan oleh Indonesia sebagai penguatan khususnya terhadap eksistensi perairan disekitar perairan kepulauan Natuna. Diplomasi perbatasan berupa negosiasi atau perundingan dengan strategi yang tepat, strategi tersebut adalah dengan lebih memfokuskan usaha penguatan ke dalam dengan membangun secara nyata daerah perbatasan sehingga penguasaan secara efektif atau effective occupation terjadi di daerah perbatasan.

\section{B. Saran}

1. Perlunya sosialisasi skala internasional secara terus menerus kepada stakeholder negara-negara terutama terkait dengan aturan-aturan prinsip delimitasi kawasan perbatasan darat dan laut berdasarkan UNCLOS 1982.

2. Perlunya peran aktif diplomasi Indonesia membangun kepercayaan dunia internasional khususnya pihak Tiongkok tentang pentingnya mematuhi putusan Lembaga-lembaga peradilan seperti PCA (Permanent Court of Arbitration).

\section{DAFTAR PUSTAKA}

Adolf Huala, Aspek-aspek Negara dalam Hukum Internasional, CV. Rajawali Pers, Jakarta. 1991.

Anonim, International Hydrographic Organization, Limits of Oceans and seas, Special Publication No.23, $3^{\text {rd }}$ Edition 1953, IMP. Moneqas que-Montecarlo, 1953.

Anonim, Limit of Ocean and Seas, International Hydographic Organization, Special Publication 23 Draft $4^{\text {th }}$ edition 1986, Published by the International Hydrographic Bureau, 1986.

Anwar Chairul, Hukum Internasional Horizon Baru Hukum Laut Internasional Konvensi Hukum Laut 1982, Penerbit Djambatan, Jakarta, 1989.

Ardhiwisastra Yudha Bakti, Penafsiran dan Konstruksi Hukum, Penerbit P.T. Alumni, Bandung, 2008.

Attard David Joseph, The Exclusive Economic Zone In International Law, Clarendon Press Oxford, New York, 1987.

Black Henry Campbell, Blacks Law Dictionary, Fifth Edition, St. Publishing Co, 1979.

Dixon Martin, International Law, Third Edition, Black Stone Limited, London, 1996. 
Kwiatkowska Barbara, The 200 Mile Exclusive Economic Zone in the New Law of the Sea, Martinus Nijhoff Publishers, Dordrecht/ Boston/ London, 1989.

Marzuki Peter Mahmud, Penelitian Hukum, Ed.1 Cetakan ke-3, Kencana Prenada Media Group, Jakarta. 2007.

Massie Cornelis Djelfie, Pengantar Hukum Kawasan Perbatasan dan Pulau-pulau Terluar Indonesia, Perspektif Hukum Laut Internasional, Pustaka Referensi, Ed 1, Yogyakarta, 2019.

Mauna Boer. "HukumInternasional, PengertianPeranan dan FungsiDalam Era Dinamika Global", Edisi ke-2, 2005, Penerbit Alumni, Bandung, 2008.

Nasution Bahder Johan, Metode Penelitian IImu Hukum, Penerbit CV. Mandar Maju, Bandung, 2008.

O'Connell D. P.. "The International Law of the Sea", Volume I, 1982, Clarendon Press, Oxford.

Pathiana I Wayan, Pengantar Hukum Internasional, Penerbit CV. Mandar Maju, Bandung, 1990.

Shaw Malcolm N., Hukum Internasional, Edisi ke-6, Penerbit Nusa Media, Bandung, 2013.

Situni A. Whisnu, Identifikasi dan Reformulasi Sumber-sumber Hukum Internasional, Penerbit C.V Mandar Maju, Bandung. 1989.

Soekanto Soerjono dan Sri Mamuji, Penelitian Hukum Normatif, Suatu Tinjauan Singkat, PT Raja Grafindo Persada, Jakarta, 2009.

Suryokusumo Sumaryo, Praktik Diplomasi, Penerbit STIH IBLAM, Jakarta Pusat, 2004.

Suryono Edy, Moenir Arisoenda, Hukum Diplomatik Kekebalan dan Keistimewaannya, Penerbit Angkasa, Bandung, 1986.

Wila Marnixon R.C., Konsepsi hukum Dalam Pengaturan dan Pengelolaan Wilayah Perbatasan Antarnegara, Kasus Wilayah Enklave Negara Timor Leste di Dalam Wilayah Negara Indonesia, Penerbit PT. Alumni, Bandung, 2006.

\section{Web \& Jurnal}

Muhammad Rafi Darajati, Huala Adolf, Idris, Putusan Sengketa Laut China Selatan serta Implikasi Hukumnya Terhadap Negara
Disekitar Kawasan Tersebut, Jurnal Hukum \& Pembangunan 48 No. 1 (2018): 22-43, ISSN: 0125-9687 (Cetak), E-ISSN: 25031465 (Online).

Nori Oktadewi, Wahyu, Politik Luar Negeri Indonesia Di Lihat Dari UU No 37 Tahun 1999 Tentang Hubungan Luar Negeri, Jurnal PIR Vol. 2 No. 2 Februari 2018 ISSN: 2528-7192

Laut China Selatan, https://id.wikipedia.org/wiki/Laut China S elatan

Putusan Lengkap Mahkamah Arbitrase Soal Laut China Selatan, https://news.detik.com/internasional/d3251971/ini-putusan-lengkap-mahkamaharbitrase-soal-laut-china-selatan.

Jumpa Duterte: Xi jinping Tolak Kemenangan Filipina atas LCS https://www.cnnindonesia.com/internasio nal/20190830124111-113-426051/jumpaduterte-xi-jinping-tolak-kemenanganfilipina-atas-Ics.

Laut China Selatan Laut yang Disengketakan, https://projects.voanews.com/southchina-sea/indonesian/recent/.

Putusan Mahkamah Internasional PBB di Den Haag, 17 Desember 2002, Dec.ICJ No.1022002 International Court of Justice, Year 200217 December General List No. 102, Case Concerning Sovereignty over Pulau Ligitan and Pulau Sipadan (Indonesia/Malaysia). 